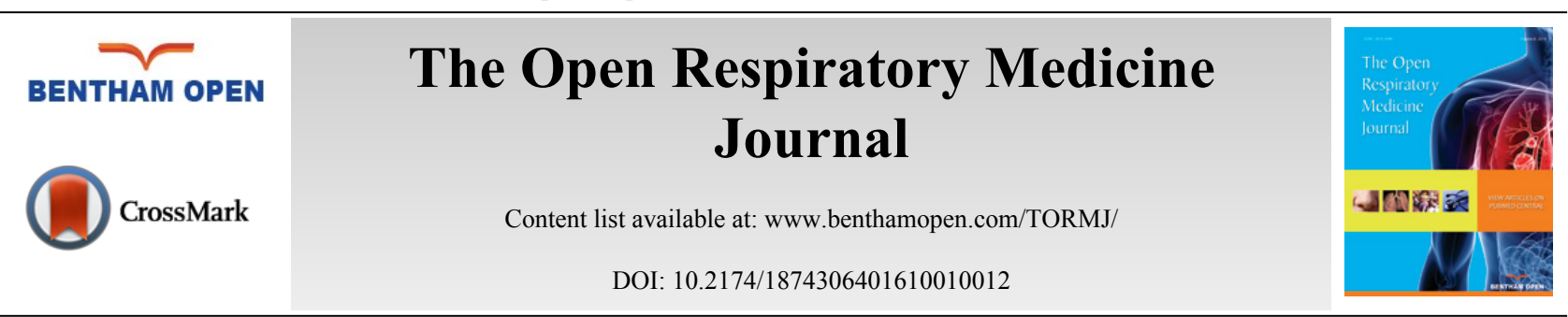

\title{
Physiotherapy Intervention During Level I of Pulmonary Rehabilitation on Chronic Obstructive Pulmonary Disease: A Systematic Review
}

\author{
Guilherme Medeiros de Alvarenga ${ }^{1,2, *}$, Humberto Remigio Gamba ${ }^{1}$, Lilian Elisa Hellman ${ }^{2}$, Vanusa \\ Ganzert Ferrari ${ }^{2}$ and Rafael Michel de Macedo ${ }^{3,4}$ \\ ${ }^{I}$ Graduate Program in Electrical and Computer Engineering from Universidade Tecnológica Federal do Paraná, \\ Curitiba, PR, Brazil \\ ${ }^{2}$ Specialization Program in Physiotherapy on Gerontology from Universidade Positivo, Curitiba, PR, Brazil \\ ${ }^{3}$ Heart Academy, Rehabilitation Service from Hospital Cardiológico Costantini, Curitiba, PR, Brazil \\ ${ }^{4}$ Graduate Program in Health Sciences, Pontifícia Universidade Católica do Paraná, Curitiba, PR, Brazil
}

\begin{abstract}
:
Background:

The progressive and chronic course of COPD, characterized by difficulty in breathing, can be aggravated by periods of increased symptoms (exacerbation). The treatment often involves in-hospital care and among the interventions applied in COPD patients, physical therapy prompts good results. However the most used techniques are not properly pinpointed and there is no consensus in the literature regarding its effectiveness.
\end{abstract}

\section{Methods:}

A systematic review was performed to identify which physical therapy treatment was applied in these cases. The following bibliographic databases were consulted: PubMed, and Bireme Portal, Periódicos Capes. Controlled randomized clinical trials that is under went physical therapy intervention in patients hospitalized for exacerbated COPD without the use of NIV (non-invasive ventilation) were included in the study. The PEDro scale, which has a score of $0-10$, was used to evaluate the quality of studies included in this review.

\section{Results:}

The electronic search yielded a total of 302 references published in English, of which only 6 met the criteria for inclusion and exclusion.

\section{Conclusion:}

It is possible to infer that physiotherapy's techniques used in patients hospitalized for COPD exacerbation, based on this review, were the high frequency chest wall oscillation (HFCWO) on the chest; relaxing massage and active exercises, electrical stimulation via electro-acupuncture; strengthening of the quadriceps; the ELTGOL bronchial drainage technique (expiration with the glottis open in the lateral posture) and an incentive spirometer.

Keywords: COPD, exacerbation, hospitalization, physiotherapy intervention.

\footnotetext{
* Address correspondence to this author at the Aristides Pereira da Cruz, n 21 casa 57 Curitiba, Paraná 80330-290, Brazil; Tel: +55 41 9962-2102; E-mails: rafael.macedo@hospitalcostantini.com.br,gmalvarenga@gmail.com
} 


\section{INTRODUCTION}

According to the consensus document of the World Health Organization - Global Initiative for Chronic Obstructive Lung Disease (GOLD), the Chronic Obstructive Pulmonary Disease (COPD) might be defined as a preventable and treatable condition, with significant extrapulmonary effects that may result in different levels of functional limitiation [1]. It is recognized as one of the main causes of death worldwide. Data from the World Health Organization (WHO) of United Nations (UN) estimates 3 million deaths per year. Besides, COPD and its comorbidities treatment costs approximatedly 50 billion euros yearly. (European Health Forum Gastein - EHFG, 2010). This represents an average cost of 5 thousand dollars per patient yearly in Europe. (ERS-European Respiratory Society, 2009) [2].

COPD's deleterious effects might present themselves chronically, as occurs in sarcopenia or acutely as in its exacerbation. The latter can result in respiratory insufficiency and some therapeutic measures are paramount. Highlighted are the following: pharmacological therapy (through the use of bronchodilators and glucocortico-steroids), antibiotics, oxygenotherapy, Non-Invastive Ventilation (NIV) and respiratory physical therapy [3, 4]. Despite the latter's recognition as an effective technique to the condition's decompensation, there is still considerable controversy as to what is the best intervention strategy. Basoglu et al. [5]. performed a randomized study involving 27 patients with the goal of comparing the results of two types of therapeutic intervention (incentive spirometer versus medication) on patients admitted for in-hospital treatment during CPOD's exacerbation. The group that underwent incentive spirometer treatment presented better clinical evolution. However, this type of resource is not recommended by international guidelines [6], since physical therapy's goal should be to dessuflate. Therefore, this population's intervention strategies are visibly controversial.

The divergent approach makes it difficult to reproduce the methods, resulting in less evidence that corroborates its effectiveness. It is known that physiotherapeutic intervention at this stage of treatment relieves dispnea, reduces ventilation work, improves pulmonary capacity and volume and minimizes effects of disuse during hospitalization [7]. Notwithstanding, which would be the best intervention methodology?

Based on that question rises this systematic review goal. Which is to identify the main physiotherapeutic intervention methods applied on COPD patients during in-hospital treatment and its benefits.

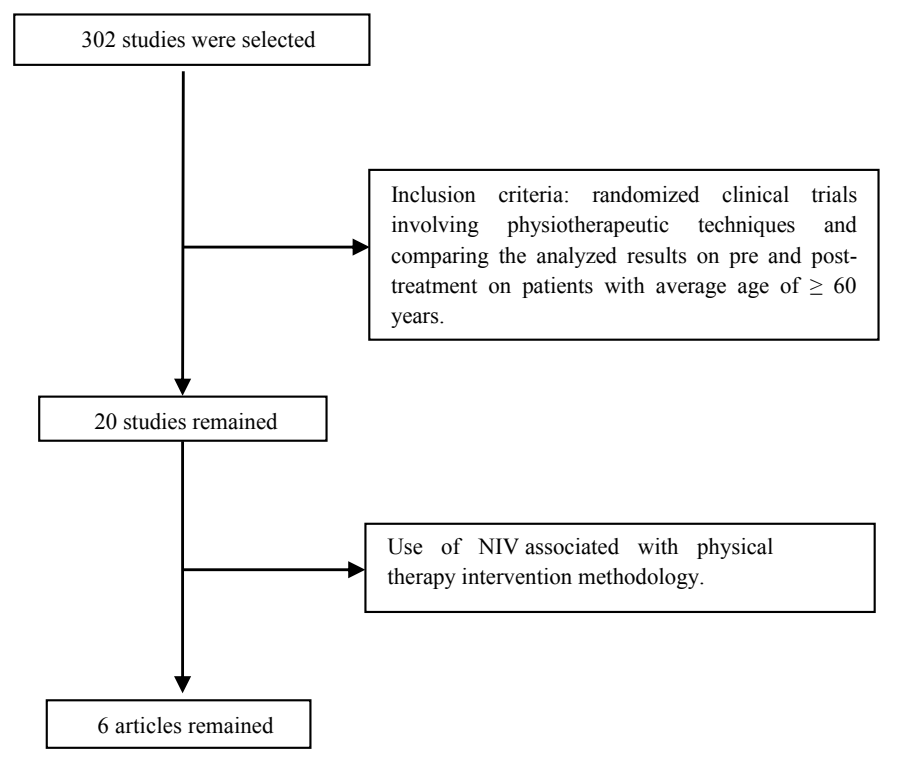

Fig. (1). Flowchart search, selection and inclusion of studies. NIV=non-invasive ventilation.

\section{MATERIALS AND METHODS}

In order to build this review, it was initially researched PubMed, Bireme and Periódicos Capes' databases using the following key-words: copd, exacerbation, intervention, physiotherapy, hospital, andAECOPD, including titles published from January of 2000 to April 2014. The search was made with each key-word at a time and with association between them. (AECOPD x hospital $\mathrm{x}$ physiotherapy), (AECOPD $\mathrm{x}$ intervention $\mathrm{x}$ physiotherapy), (copd $\mathrm{x}$ intervention $\mathrm{x}$ physiotherapy), (copd $\mathrm{x}$ exacerbation $\mathrm{x}$ hospital), (copd $\mathrm{x}$ hospital $\mathrm{x}$ physiotherapy) and (copd $\mathrm{x}$ exacerbation $\mathrm{x}$ 
intervention x physiotherapy x hospital x AECOPD). Initially, three independent reviewers (G.A., V.G., L.H.) assessed all selected titles. ( $\mathrm{n}=302$, of which: 177 found on PubMed, 17 on Bireme and 108 on Periódicos Capes). They analyzed the document's abstracts based on the inclusion criteria of the study: randomized clinical trials involving physical therapy techniques that compared pre and post intervention results on patients with average of $\geq 60$ years old. Twenty studies were selected according to the aforementioned filters. All articles involving physical therapy techniques combined with NIV $(n=6)$ were excluded from the selection, because this paper's objective is to asses different methods without the use of artificial ventilation (Fig. 1).

The article's full texts that were deemed potentially relevant were retrieved for a final assesment, and its references list was checked independently by the same reviewers in order to identify additional studies that could fit into the criteria and did not show on the initial electronic search.

The studies methodological relevance was assessed based on the PEDro scale, based on Delphi's list. Although that scale has 11 questions, only 10 receive scores, so the scale goes from $0-10$. Each criteria is counted according to its presence or absence on the evaluated study. Every item met, except for the first, adds one level on the scale. The items not described on the study do not have score and are labeled as "undescribed". Final score is obtained by the sum of all positive answers $[8,9]$.

\section{RESULTS AND DISCUSSION}

Of all articles included on this review, none used the same technique and/or resource as treatment of choice to apply on patients admitted to the hospital, due to COPD's exarcebation. Besides, all articles presented a low number of participants, which reflects the evidence frailness provided by literature regarding those different methodologies. Among the techniques found on this review, the following could be enphasized: high-frequency chest wall oscillation (HFCWO), thorax relaxation techniques, active exercises of peripheral joints, walks, electrical stimulation via TENS, acupuncture, strengthening of the quadriceps muscles, the ELTGOL bronchial drainage technique (expiration with the glottis open in the lateral posture) and Incentive Spirometer (Table 1).

It's important to highlight that all patients involved in this study's sample were under clinical optimized pharmacological treatment. This treatment followed the guidelines of Global Initiative for Chronic Obstructive Lung Disease-GOLD [1], being ministred to patients salbutamol, ipratropium bromide, theophylline and methylprednisolone.

Mahajan et al. [10], in the study, evaluated the impact of high frequency chest wall oscillation on hospitalized patients due to exacerbated COPD and asthma $(n=52)$. The patients were divided in two groups (control group ( $n=27)$ and experimental group $(n=25)$. The pre and post treatment evaluation was done through a satisfaction questionnaire, the Modified Borg Scale, Spirometry and expectoration volume. In total, during four days of the hospital stay, physical therapy was performed three times a day of 15 minutes each. The treatment itself consisted on applying a high frequency oscillation through an inflatable vest that generates air pulses, creating compressions to the participant's chest wall. On this study, the participants of the experimental group presented higher level of comfort after the intervention and had the dispnea index significantly reduced.

High-frequency chest wall oscillation (HFCWO) is a technique applied to mobilize secretion from the airways [11]. One way of producing this oscillation is through inflatable vests. This system allow people to have their airways cleaned without the need of a specific positioning or coordinated expiration, and may be administered with minimal therapeutic support.

These vests are composed of inflatable clothing connected by tubes of an air impulse generator, producing quick and smooth compressions (oscillations) to the chest wall. Those generate an increase on the air flow speed that resemble the one from coughing, facilitating secretion expectoration [12 - 14], which can justify the improvement of the symptoms described by the samples from the study done by Mahajan et al. [10].

Kurzaj et al. [15], assessed the efficacy of physiotherapeutic methods measured by the BODE index, in COPD patients during hospitalization. The study comprised of 30 patients (divided in control and experimental groups) that were submitted to standard pharmocological treatment (groups of drugs: anticholinergics, B2-sympathomimetics and theophylline derivatives, intravenous and oral doses of corticosteroids and non-invasive ventilation and oxygen therapy had not been used), along with physical therapy. On the experimental group a serie of six additional massages, during a few days, were made to remodel the following muscles: sterocleidomastoid, pectoralis major and minor, trapezius, levator scapulae, rhomboids and serratus anterior. Each massage had 30 minutes of duration, using massage and kneading techniques. 
The results analysis demonstrated improvement on the exercise group in all BODE's items, except the BMI; reduction of FEV1 (Forced Expiratory Value in one second) on both groups; on the 6MWT (6-minute walk test) both groups presented improvement, although more significantly on the experimental group. MRC Dyspnea Scale decreased on the exercise group. Those patients displayed low tolerance to exercise and consequently, low calorie consumption, which would explain the lack of significant results regarding the BMI analysis. Massage therapy, with its muscle alignment techniques, and trigger point treatment for relaxation applied to the acessory muscles of respiration contributed to muscles length improvement, and by consequence, its force, considering that until then this group of muscles were overloaded by increased respiratory work, and COPD's exacerbation. Those findings corroborate the ones from Ries et al. [16] that demonstrated that dyspnea and anxiety levels reduced drastically due to muscle relaxation of 16 different muscle groups on COPD patients.

Table 1. Features of the articles in this systematic review.

\begin{tabular}{|c|c|c|c|c|}
\hline Authors & Sample & Methodology & Outcome Measures & Results \\
\hline $\begin{array}{c}\text { Mahajan et al. } \\
\text { [10] (2011) }\end{array}$ & 52 & $\begin{array}{c}4 \text { sessions/3 times a day/ } 15 \text { minutes each } \\
\text { (exercise group vs control group) received } \\
\text { high frequency Chest Wall Oscillation } \\
\text { (HFCWO). }\end{array}$ & \begin{tabular}{|} 
Satisfaction questionnaire; Borg's \\
Modifed Scale; Expectoration volume; \\
Spirometry (FEV1).
\end{tabular} & $\begin{array}{l}\text { The exercise group presented improved } \\
\text { dyspnea sensation when compared to the } \\
\text { control group; the remaining assessed } \\
\text { items did not present meaningful results. }\end{array}$ \\
\hline $\begin{array}{l}\text { M. Kurzaj et } \\
\text { al. }[15] \\
(2013)\end{array}$ & 30 & $\begin{array}{l}7 \text { days, same time and therapist (exercise } \\
\text { group vs control)/all used standard } \\
\text { medication and performed exercises for } \\
\text { thorax relaxation, and abdominal exercise } \\
\text { with expanded expiration. Active exercises } \\
\text { of perpheral joints, walk } 150 \mathrm{~m} / \text { dia). } \\
\text { Exercise Group: } 30 \text { minutes of massage on } \\
\text { muscles of respiration }\end{array}$ & $\begin{array}{c}\text { BODE's Index; Spirometry (FEV1); 6- } \\
\text { minutes Walk Test (6MWT); MRC } \\
\text { Scale and BMI. }\end{array}$ & $\begin{array}{l}\text { all BODE's items, except BMI, } \\
\text { improved on the exercise group. } \\
\text { Reduction of FEV1 (both groups); on } \\
\text { 6MWT both groups presented } \\
\text { improvement, more significantly on the } \\
\text { exercise one. MRC dyspnea scale } \\
\text { decreased on exercise group. }\end{array}$ \\
\hline $\begin{array}{l}\text { Ngai et al. } \\
\text { [18] (2013) }\end{array}$ & 1 & $\begin{array}{l}\text { TENS on acupuncture point (EX-B1 } \\
\text { (Dingchuan) for } 45 \text { minutes. Associated to } \\
\text { oxygen therapy ( } 2 \mathrm{~L} / \mathrm{min})\end{array}$ & \begin{tabular}{|c|} 
Oxygen saturation, Cardiac Frequency, \\
and dyspnea score. b-endorphin level \\
assessment, White Blood cells count \\
(WBC), Tumor Necrosis Factor alpha \\
(TNF-a) and C-reactive protein (CRP).
\end{tabular} & $\begin{array}{c}\text { Improvement of oxygen saturation, e } \\
\text { decrease of cardiac and respiratory } \\
\text { frequency, dyspnea feeling. Increase of b- } \\
\text { endorphin levels; WBC, o TNF-a and } \\
\text { CRP remained unaltered. } \\
\end{array}$ \\
\hline $\begin{array}{l}\text { Troosters, } \\
\text { Thierry et al. } \\
{[21](2010)}\end{array}$ & 30 & $\begin{array}{l}8 \text { days, control group did respiratory } \\
\text { physical therapy while the other group had } \\
\text { quadriceps strenghtening on a knee- } \\
\text { extension chair with initial resistance of } \\
70 \% 1 \text { RM. Performing } 3 \text { series of } 8 \\
\text { repetition and load adjustments were } \\
\text { symptoms-oriented. }\end{array}$ & $\begin{array}{l}\text { The quadriceps MVC was assessed on } \\
\text { day } 2,8 \text { and a month post discharge. } \\
\text { Tolerance to functional exercise and } \\
\text { pulmonar function were assessed on } \\
\text { discharge and a moth there after. } \\
\text { Dyspnea symptoms were evaluated } \\
\text { using MRC (Medical Research } \\
\text { Council) Dyspnea Scale on the day of } \\
\text { discharge and a month later. The } \\
\text { 6MWT was performed in the } \\
\text { beginning at hospitalization and again } \\
\text { after the treatment. }\end{array}$ & $\begin{array}{l}\text { During exacerbation, MVC increased } \\
\text { significantly more on the training group } \\
\text { in comparison to the control one.. A } \\
\text { month after the MVC remained } \\
\text { unaltered comparing to the ones at } \\
\text { discharge. The 6MWT improved after } \\
\text { discharge of the training group, but } \\
\text { remained unaltered on the control group. }\end{array}$ \\
\hline $\begin{array}{c}\text { Kodric et al. } \\
\text { [2] (2009) }\end{array}$ & 59 & $\begin{array}{l}\text { Divided in } 2 \text { groups. The first received } \\
\text { medication and ELTGOL } 30 \text {-minute session } \\
\text { technique, during } 7 \text { days, twice a day, } \\
\text { performed by the same therapist. The second } \\
\text { group was treated only with medication. }\end{array}$ & \begin{tabular}{|} 
Expectoration volume, period of \\
hospitalization, Spirometry, O2 \\
saturation, dyspnea decrease \\
(Borg's), improvement of \\
life quality (St George Respiratory \\
Questionnaire) and incidence of COPD \\
exacerbation during post-hospitalization \\
follow-ups.
\end{tabular} & $\begin{array}{l}\text { There was no significant differences on } \\
\text { the amount of mucus produced by the } \\
\text { groups. But group } 1 \text { had higher reduction } \\
\text { of sputum's volume. Similar results on } \\
\text { both groups regarding period of } \\
\text { hospitalization. Group } 1 \text { had slight } \\
\text { improvement of dyspnea. Life quality } \\
\text { evaluated a month after discharge was } \\
\text { similar on both groups. }\end{array}$ \\
\hline $\begin{array}{l}\text { Basoglu et } \\
\text { al. }[5] \\
(2005)\end{array}$ & 27 & $\begin{array}{l}\text { Divided in } 2 \text { groups. Control group } \\
\text { received only medication. The experiment } \\
\text { group performed } 10 \text { inspiration per hour, } \\
\text { during } 2 \text { months. (incentive spirometer with } \\
\text { medication vs medication only). Patients } \\
\text { remained around } 10 \text { days in-hospital and } \\
\text { received follow-ups at home. }\end{array}$ & $\begin{array}{l}\text { Pulmonary function and gasometry, } \\
\text { dyspnea assessment via Visual } \\
\text { Analogue Scale (VAS) and life quality } \\
\text { was assessed through the St George } \\
\text { Respiratory Questionnaire (SGRQ). }\end{array}$ & $\begin{array}{l}\text { The experiment group presented } \\
\text { improvement on measurements made } \\
\text { pre and post-treatment on SGRQ and } \\
\text { ongasometry values. However, the } \\
\text { control group displayed virtually no } \\
\text { differences for these parameters. }\end{array}$ \\
\hline
\end{tabular}

Besides, Progressive Muscle Relaxation (PMR) aims to drive the patient into a deep muscle relaxation state. According to the author this state could reduce the large activation of the central nervous system (CNS), and the autonomic nervous system (ANS), and restoring or promoting physical and psychological well-being given the relation of the emotional state with the bodily one [17]. 
Ngai et al. [18], reported a case in which the transcutaneous electrical nerve stimulation (TENS) on acupuncture points were performed to verify its efficacy on relieving dyspnea on stable COPD patients. The patient was a 74 yearold male, hospitalized due to acute exacerbation. TENS were applied on the acupuncture point EX-B1 (Dingchuan) for 45 minutes. Oxygen saturation, heart frequency and dyspnea score were measured before, immediately after, and 45 minutes after intervention. As a result, the oxygen saturation improved, and heart frequency and dyspnea were reduced, therefore, relieving the patient's symptoms.

With in Traditional Chinese Medicine (TCM), the maintenance of health and balancing of the body and its functions derives of a resultant of "yin" and "yang" and the free flow of energy (Qi), running through different body meridians. Studies demonstrate that acupuncture, a technique that facilitates the free flow of the Qi, may relieve dyspnea symptoms, diminish post-exercise bronchoconstriction and improve respiratory capacity [19, 20]. Despite that, it's important to highligh that it was merely one case study.

Included on the techniques identified on this review is the quadriceps strengthtening performed on Troosters et al. study [21]. Thirty-six hospitalized COPD's patients due to exacerbation took part on the study. They were divided in two groups: the control, and the training one. In order to evaluate the effects of this treatment course measurements of Maximum Voluntary Contraction (MVC) of the quadriceps were taken on the second day of hospitalization, on the eighth day, and a month after patient's discharge. Tolerance to functional exercise (6-minute Walk Test) and pulmonary function (Spirometry) were measured at discharge and one month afterwards. Dyspnea symptoms were measured by the MRC Dyspnea Scale, on the day of admittance into the hospital and a moth after discharge.

During hospitalization, the patients on the control group received standart care, with medication and physical therapy exclusively of desobstruction techniques and respiratory exercises according to the patient's clinical condition and although the patients had no restrictions regarding physical activity, no official instructions were provided on that matter. On the other hand, the training group received the stardard care, and in addition, daily training were performed for 7 days on a knee extension chair. The initial load was set to 70\% of 1RM (1 Repetition Maximum: the maximum load that can be moved only once during full range of motion without compensations). Three series of eigh repetitions were performed, and the load determination was made by the symptoms on Borg's dyspnea score. As a result, tendency of improvement was identified regarding FEV1 on the control group, and both groups remained hospitalized for the same amount of days. The quadriceps strength was higher on the training group when compared to the control one during discharge and a month after hospitalization. The distance achieved on the 6MWT improved only on the training group.

It is important to stress that the patients who have undergone this kind of treatment had a compensated COPD status, which determines with full the assistance in level 1 of pulmonary rehabilitation program. Patients hospitalized by decompensated COPD will initially be submited to chest physical therapy techniques that aim to re-establish lung's volume and capacities, rebalancing oxygen supply and intake. Once compensated, the patient is then able to receive physical exercise that require greater energetic consumption. As of this moment, interventions such as the training suggested by Troosters et al. [21] would benefit the patients minimizing the effects of lack of muscle use caused by hospitalization period [22]. Diminished strength on COPD carriers occurs mainly on lower limbs. Gosselink et al. [23] showed that weakening of the quadriceps is significantly higher than on pectorals, latissimus dorsi. On the upper limbs the strength loss is higher on the soulder's proximal muscles [24]. To this date, there is still not enough studies and, therefore, there is no consensus about the strength training on patients with chronic pulmonary disease. Two types of strenghtening are found on literature: Moderate to high intensity based on relative intesities (50-90\%) of a Repetition Maximum; and the light weight or body segment's own counter-resistance [25 - 27].

A study performed by Pitta et al. [7], found that patients hospitalized due to COPD's acute exacerbation had low level of physical activity during and afer in-hospital care, and there was significant reduction of quadriceps strength in that same period. That reinforces the importance of muscle strength exercises on this region in the hospital environment. According to Langer et al. [6] it is recommended to apply training that enable patients to take part on the rehabilitation program after an acute exacerbation as soon as possible. As an alternative, there is the interval training, the strength or electrical neuromuscular stimulation, which can be used to immediately recrute muscle fibers and prevent further functional decline.

Kodrick et al. [28], assessed the efficacy of the respiratory technique ELTGOL (expiration with open glottis on lateral posture) during COPD acute exacerbations, using as measurement expectorarion volume, time of hospitalization, Borg's Scale for Dyspnea, quality of life via St. George Respiratory Questionnaire, and exarcebation incidence during 
post hospitalization follow-up. Fifty nine hospitalized patients for acute COPD exacerbation were divided in two groups. The first received medication and ELTGOL 30-minute sessions, for 7 days, twice a day. The latter was treated only with bronchodilator medication. Regarding mucus expectoration no significant differences were found. Both groups had similar results concerning hospitalization period. Regarding the Dyspnea the first group had better results, although with little margin. Quality of life, assessed a month folowing discharge, was similar on both groups. According with Guimaraes et al. [29], ELTGOL consists in performing slow expirations with the glottis open, from residual functional capacity (FRC) to the residual volume. (RV) with the indivual on lateral decubitus position, with the affected lung on dependent position. ELTGOL is indicated on cooperative patients with hypersecretion, and on patients in which forced maneuvers might cause constrictions or proximal colapses that jeopardize secretion elimination [30].

ELTGOL is a bronchial desobstruction technique, which doesn't distinguish physical training stimuli for distinguish physical exercise training. This explains the lack of difference on life quality a month post-discharge, since physical ability was not stimulated.

Basoglu et al. [5], performed a study to verify incentive spirometer efficiency on patient's COPD exacerbation while hospitalized. Thirty-two patients were recruted and separated in two distinct groups. The first was treated with medication and flow-oriented incentive spirometers. The second, was treaded solely on medication. As the study progressed 5 individuals were excluded. At the end, only 27 volunteers were reassessed. All patients were hospitalized for an average of ten days and received residential follow-ups. The first evaluation happened on day of admission into the hospital, the three following were performed over the phone every two weeks, and the fifth and last evaluation was done again at the hospital after two months of initial admittance. The requisites were analyzed as pre and post treatment on both sets, and the incentive spirometer therapy was performed on the first day and sustained at home until the two subsequent months. The final measurements examinated on this study were pulmonary function, gasometry, Dyspnea assessment through VAS (Visual Analogue Scale), and life quality through the St. George Respiratory Questionnaire (SGRQ). Results showed the first group presented improvement on measurements done as pre and post treatment on SGRQ and on gasometry values. However, the second group had no significant differences for these same parameters. As per studies [31,32], the incentive spirometer are equipments designed to stimulate deep slow inspiration, sustained with visual stimuli, being flow or volume-oriented. They are mechanic devices that encourage patients to hyperinsuflate their lungs. They are indicated to restablish respiration pattern to prevent and revert alveoli from collapsing. Physiologically, incentive spirometers increase transpulmonary pressure and inspiratory volume, improve inspiratory muscles performance, and re-establish the pulmonary expansion pattern, which might beneficiate the cough mechanism. However, it is worth stressing that the method applied on this study, using deep inhalation doesn't reproduce or follow Langer et al. [6] guidelines, since those contraindicate incentive spirometers, but prescribes exercises to treat lungs' hyperinsufflation through active exhalation and pursed-lip breathing (PLB).

On the authority of Jadad et al. [33] and Guyatt et al. [34], randomized controlled clinical trials present lower risk of methodological bias on participant's selections and therefore provide safer evidence to plan new interventions. As stated by Verhagen et al. [35], the validity of a systematic review's conclusion relies on the quality of primary studies included on it. Notwithstanding, this statement guided the selection of articles for this review, most of the studies herein presented methodological limitations. The main flaws were related to the lack of proper description of the randomization and evaluator blinding procedures, with the studies scoring an average of 4.8 out of 10 .

\section{CONCLUSION}

The physiotherapeutic techniques or interventions applied to the hospitalized patients due to COPD were: physical exercise (quadríceps strengthening), respiratory exercises and techniques such as ELTGOL, high frequency chest wall oscillation (HFCWO), and the use of incentive spirometers, and electro-acupuncture. It was observed that, the wide methodological variation prevented the production of higher level of evidence.

Different techniques are used in hospitals as a result of the low level of evidence as to the technical and physical therapy resources. This low level of evidence is the basis for the practice of personal experiences which makes the standardization of techniques for better results more difficult. Therefore, this review study showed that the problem needs to be solved through scientific development.

Hence, it becomes clear, the need of performing more randomized studies involving this population and the physiotherapeutic intervention techniques. 


\section{REVIEW LIMITATION}

Low number of patients included on the assessed studies.

\section{CONFLICT OF INTEREST}

The authors confirm that this article content has no conflict of interest.

\section{ACKNOWLEDGEMENTS}

Declared none.

\section{REFERENCES}

[1] Vestbo J, Agusti A, Anzueto A, et al. The global strategy for diagnosis, management and prevention of COPD (updated 2010). Global Initiative for chronic obstructive pulmonary disease (GOLD). Available from: www.goldcopd.com 2010.

[2] Sociedade Brasileira de Pneumologia e Tisiologia [homepage onthe Internet]. Brasília: Sociedade Brasileira de Pneumologia e Tisiologia [updated: 2012 Jun; cited 2014 Jun]. DPOC e Saúde Pública - Atendendo as necessidades dos pacientes. [Adobe Acrobat document, 17p.]. Available from: http://www.sbpt.org.br/downloads/arquivos/COM_DPOC/Relatorio_final_DPOC_Saude_Publica_2012_SBPT.pdf

[3] Celli BR, Macnee W, Agusti A, et al. Standards for the diagnosis and treatment of patients with COPD: a summary of the ATS/ERS position paper. Eur Respir J 2006; 27(1): 242. [PMID: 15219010]

[4] Tang CY, Taylor NF, Blackstock FC. Chest physiotherapy for patients admitted to hospital with an acute exacerbation of chronic obstructive pulmonary disease (COPD): a systematic review. Physiotherapy 2010; 96(1): 1-13. [http://dx.doi.org/10.1016/j.physio.2009.06.008] [PMID: 20113757]

[5] Basoglu OK, Atasever A, Bacakoglu F. The efficacy of incentive spirometry in patients with COPD. Respirology 2005; 10(3): 349-53. [http://dx.doi.org/10.1111/j.1440-1843.2005.00716.x] [PMID: 15955148]

[6] Langer D, Probst VS, Pitta F, et al. Guia para Prática Clínica: Fisioterapia em pacientes com Doença Pulmonar Obstrutiva Crônica (DPOC). Rev Bras Fisioter 2009; 13(3): 183-204. [http://dx.doi.org/10.1590/S1413-35552009005000034]

[7] Pitta F, Troosters T, Probst VS, Spruit MA, Decramer M, Gosselink R. Physical activity and hospitalization for exacerbation of COPD. Chest 2006; 129(3): 536-44 [http://dx.doi.org/10.1378/chest.129.3.536] [PMID: 16537849]

[8] PEDro - Physiotherapy Evidence Database [homepage da internet]. Australian: The center for evidence-based physiotherapy. [acessoem 06/06/2014]. Disponívelem: www.pedro.org.au.

[9] Verhagen AP, de Vet HC, de Bie RA, et al. The Delphi list: a criteria list for quality assessment of randomized clinical trials for conducting systematic reviews developed by Delphi consensus. J Clin Epidemiol 1998; 51(12): 1235-41. [http://dx.doi.org/10.1016/S0895-4356(98)00131-0] [PMID: 10086815]

[10] Mahajan AK, Diette GB, Hatipoğlu U, et al. High frequency chest wall oscillation for asthma and chronic obstructive pulmonary disease exacerbations: a randomized sham-controlled clinical trial. Respir Res 2011; 12: 120. [http://dx.doi.org/10.1186/1465-9921-12-120] [PMID: 21906390]

[11] Paschoal IA, Villalba WO, Pereira MC. Insuficiência respiratória crônica nas doenças neuromusculares: diagnóstico e tratamento. J Bras Pneumol 2007; 33(1): 81-92. [http://dx.doi.org/10.1590/S1806-37132007000100016] [PMID: 17568873]

[12] High-Frequency chest wall oscillation for airway clearance in neuromuscular dysfunction [homepage da internet]. República Checa: Dartin [update 2012; cited 2014 Jun]. [Adobe Acrobat document, 6p.]. Disponível em: http://www.dartin.cz/files/files/ soubory_download/the vest/LaRusso\%20-\%20HFCWO\%20in\%20NMD\%20Whitepaper\%20r ev6.pdf

[13] Fink JB, Mahlmeister MJ. High-frequency oscillation of the airway and chest wall. Respir Care 2002; 47(7): $797-807$. [PMID: 12088550]

[14] Hansen LG, Warwick WJ. High-frequency chest compression system to aid in clearance of mucus from the lung. Biomed Instrum Technol 1990; 24(4): 289-94.

[PMID: 2390665]

[15] Kurzaj M, Wierzejski W, Dor A, Stawska J, Rożek K. The impact of specialized physiotherapy methods on BODE index in COPD patients during hospitalization. Adv Clin Exp Med 2013; 22(5): 721-30. [PMID: 24285458]

[16] Ries AL. The importance of exercise in pulmonary rehabilitation. Clin Chest Med 1994; 15(2): $327-37$. [PMID: 8088096]

[17] Geiza GL, Moacir FG. Estudo da aplicação da técnica de relaxamento muscular progressivo de Jacobson modificada nas respostas das variáveis cardiovasculares e respiratórias de pacientes hansenianos. Arq Ciênc Saúde 2007; 14(3): 175-80. 
[18] Ngai SP, Jones AY, Hui-Chan CW, Ko FW, Hui DS. An adjunct intervention for management of acute exacerbation of chronic obstructive pulmonary disease (AECOPD). J Altern Complement Med 2013; 19(2): 178-81. [http://dx.doi.org/10.1089/acm.2011.0222] [PMID: 22775329]

[19] Joos S, Schott C, Zou H, Daniel V, Martin E. Immunomodulatory effects of acupuncture in the treatment of allergic asthma: a randomized controlled study. J Altern Complement Med 2000; 6(6): 519-25. [http://dx.doi.org/10.1089/acm.2000.6.519] [PMID: 11152056]

[20] Ngai SP, Jones AY, Hui-Chan CW. Acu-TENS and postexercise expiratory flow volume in healthy subjects. Evid Based Complement Alternat Med 2011; 2011(8521): 726510. [PMID: 21331338]

[21] Troosters T, Probst VS, Crul T, et al. Resistance training prevents deterioration in quadriceps muscle function during acute exacerbations of chronic obstructive pulmonary disease. Am J Respir Crit Care Med 2010; 181(10): 1072-7. [http://dx.doi.org/10.1164/rccm.200908-1203OC] [PMID: 20133927]

[22] Trevisan ME, Porto AS, Pinheiro TM. Influência do treinamento da musculatura respiratória e de membros inferiores no desempenho funcional de indivíduos com DPOC. Fisioter Pesq 2010; 17(3): 209-13.

[23] Gosselink R, Troosters T, Decramer M. Peripheral muscle weakness contributes to exercise limitation in COPD. Am J Respir Crit Care Med 1996; 153(3): 976-80 [http://dx.doi.org/10.1164/ajrccm.153.3.8630582] [PMID: 8630582]

[24] Dourado VZ, Godoy I. Recondicionamento muscular na DPOC: principais intervenções e novas tendências. Rev Bras Med Esporte 2004; 10(4): 51517.

[http://dx.doi.org/10.1590/S1517-86922004000400010]

[25] Silva EG, Dourado VZ. Treinamento de força para pacientes com doença pulmonar obstrutiva crônica. Rev Bras Med Esporte 2008; 14(3): 231-8. [http://dx.doi.org/10.1590/S1517-86922008000300014]

[26] Trevisan ME, Porto AS, Pinheiro TM. Influência do treinamento da musculatura respiratória e de membros inferiores no desempenho funcional de indivíduos com DPOC. Fisioter Pesq 2010; 17(3): 209-13.

[27] Pauwels RA, Buist AS, Ma P, Jenkins CR, Hurd SS. Global strategy for the diagnosis, management, and prevention of chronic obstructive pulmonary disease: National Heart, Lung, and Blood Institute and World Health Organization Global Initiative for Chronic Obstructive Lung Disease (GOLD): executive summary. Respir Care 2001; 46(8): 798-825.

[PMID: 11463370]

[28] Kodric M, Garuti G, Colomban M, et al. The effectiveness of a bronchial drainage technique (ELTGOL) in COPD exacerbations. Respirology 2009; 14(3): 424-8.

[http://dx.doi.org/10.1111/j.1440-1843.2008.01466.x] [PMID: 19192230]

[29] Guimarães FS, Moço VJ, Menezes SL, et al. Efeitos da ELTGOL e do Flutter ${ }^{\circledR}$ nos volumes pulmonares dinâmicos e estáticos e na remoção de secreção de pacientes com bronquiectasia. Rev Bras Fisioter 2011; 16(2): 51413.

[30] Martins JA, Andrade AD, Assis RS, et al. The effects of ELTGOL on mucociliary clearance in patients with COPD. Eur Respir Rev 2006; 15(101): 192-3. [http://dx.doi.org/10.1183/09059180.00010120]

[31] Pascotini FS, Ramos MC, Silva AM, Trevisan ME. Espirometria de incentivo a volume versus a fluxo sobre parâmetros respiratórios em idosos. Fisioter Pesq 2013; 20(4): 355-60.

[http://dx.doi.org/10.1590/S1809-29502013000400009]

[32] Guimarães MM. Efetividade e segurança do inspirômetro de incentivo para prevenção de complicações pulmonares pós-operatórias em cirurgia abdominal alta: revisão sistemática e metanálise. São Paulo: Unifesp 2010. dissertação

[33] Jadad AR, Moore RA, Carroll D, et al. Assessing the quality of reports of randomized clinical trials: is blinding necessary? Control Clin Trials 1996; 17(1): 1-12.

[http://dx.doi.org/10.1016/0197-2456(95)00134-4] [PMID: 8721797]

[34] Guyatt GH, Cook DJ, Sackett DL, Eckman M, Pauker S. Grades of recommendation for antithrombotic agents. Chest 1998; 114(5)(Suppl.): 441S-4S. [http://dx.doi.org/10.1378/chest.114.5_Supplement.441S] [PMID: 9822056]

[35] Verhagen AP, de Vet HC, de Bie RA, Boers M, van den Brandt PA. The art of quality assessment of RCTs included in systematic reviews. J Clin Epidemiol 2001; 54(7): 651-4.

[http://dx.doi.org/10.1016/S0895-4356(00)00360-7] [PMID: 11438404]

Received: December 15, 2014

(C) de Alvarenga et al.; Licensee Bentham Open.

This is an open access article licensed under the terms of the Creative Commons Attribution-Non-Commercial 4.0 International Public License (CC BY-NC 4.0) (https://creativecommons.org/licenses/by-nc/4.0/legalcode), which permits unrestricted, non-commercial use, distribution and reproduction in any medium, provided the work is properly cited. 